
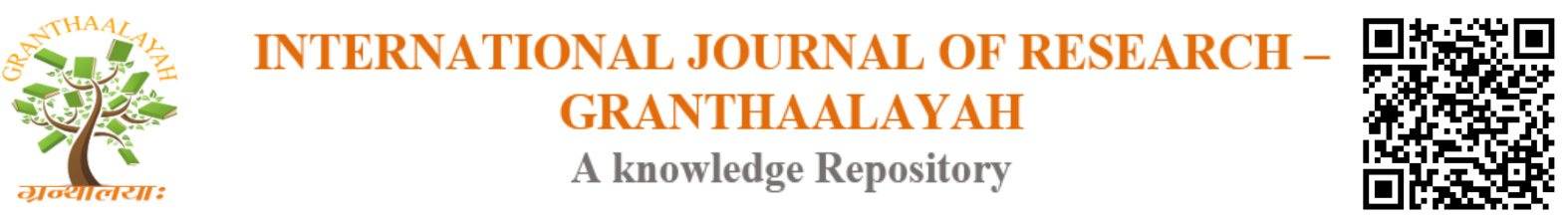

Social

\title{
PINTAKASI: A UNIFYING FACTOR IN A LOCAL VILLAGE IN THE PHILLIPINES
}

\author{
Dennis M. Bautista ${ }^{* 1}$, Charles S. Abanilla ${ }^{2}$, Ariel E. Matillano ${ }^{3}$, Allan M. Abiera 4 \\ ${ }^{*} 1,2,3,4$ Social Science Unit, College of Arts and Sciences Leyte Normal University \\ Tacloban City, Philippines
}

\begin{abstract}
This is a case study conducted in one of the rural barangays of Leyte. Anchored on the theory of collective effervescence, this study delved into an understanding of a long ago practiced tradition that still thrives even in present times. In synergy, these rural folks enthusiastically come together to solve a problem of any member of the community. Thus, this study has two major concerns: first is to investigate how and why the "pintakasi or bayanihan" spirit of the past still evident today; and second, to rediscover which aspect of the "pintakasi or bayanihan" spirit and the ancient Filipino value hold true in contemporary times. Such queries were answered using a qualitative research approach specifically the ethnographic method in gathering data coupled with a face-to-face interview with ten (10) respondents who were the community officials and elders of this said barangay to discover their social activities and values. As revealed in this study, the rural folks continuously observed the practice because it is innate to them to help especially those in need.
\end{abstract}

Keywords: Filipino Values; Voluntary Assistance; Reciprocity; Communal Work; Ethnographic Method.

Cite This Article: Dennis M. Bautista, Charles S. Abanilla, Ariel E. Matillano, and Allan M. Abiera. (2017). "PINTAKASI: A UNIFYING FACTOR IN A LOCAL VILLAGE IN THE PHILLIPINES." International Journal of Research - Granthaalayah, 5(12), 53-65. https://doi.org/10.29121/granthaalayah.v5.i12.2017.473.

\section{Introduction}

To be is to be with (esse est co-esse) was one of the famous lines of Gabriel Marcel. This may simply mean that we exist because of others. Man as a social being, was created to co-exist and be the source of perfection of other beings. The bible and other school of thoughts taught us about this concept of cooperation which is universally accepted and practiced. Even Karl Max who was misinterpreted to have denied such idea actually accepted the same. Cooperation for him is a spirit that binds man together as one nation and not the class conflict. Another theorist named Adam Smith whose capitalist principle of laissez faire made mention of each one for himself. Since man cannot exist without other beings, he is obliged to cooperate with them. 
The cooperation manifested by the people led to the establishment of societies. In ancient times, members of a society, does voluntary work as a sign of his oneness with the other members of the same. Man depends on the assistance of his fellow man whenever he has projects or things to be dealt with. This voluntary assistance that was later known as communal labor exchange became a tradition among societies. Such tradition varies according to the culture to which it is practiced. They called it differently and in the Philippines, such widely known concept is called "Pintakasi" or "Bayanihan".

What is pintakasi or bayanihan and how did the Filipinos come up with such idea? The term pintakasi may have been derived from the Bicolano term "pintacasi" as it appears in the Vocabulario de la Lengua Bicol authored by Fr. Marcus de Lisboa and published in 1865. The term is equated to the Spanish term "abogado" and "intercessor". The Spanish term "abogado" refers to somebody who is a counsel whose duty is to plead and defend. The term "intercessor" likewise refers to a person who intervenes on behalf of another. Pintakasi, therefore, is an activity wherein people would plead, intervene, and defend on behalf of another. As an activity, it was utilized to solicit from community members anything to the help both church and community projects. In the olden times, communities would contribute to the extent of sponsoring cockfighting events to generate funds. The funds collected would be used to help the needs of the people. That is why cock fight derby is known also as pintakasi among Bisayan speaking Filipinos.

Bayanihan in the other hand may have come from the Tagalog term "bayan", referring to a country, town, settlement or community. If viewed in another perspective, the term pintakasi or bayanihan would mean for them as, "Community Spirit" or an action of people extending a hand to others. Indeed, the said term sometimes refers to a spirit of community effort to achieve objective. This type of spontaneous cooperation, which calls for teamwork, is also found in the network of informal groupings of large-scale bureaucratic organizations. And such actions are called bayanihan or damayan (voluntary cooperation) throughout the country (Panopio, 2004).

Another concept about the origin of the term bayanihan, may come from the word bayani which means hero. As mentioned earlier, the said concept boils down to the idea of community spirit. In tagalog it may also means "damayan" (help in need), "kawanggawa"(charity), or even the boarder term "tulong" (help) which all mean the same when translated to English, helping others or community spirit (Veneracion,,1996). That is why, more often than not, every time we hear the term, we would always see people helping each other carrying a nipa hut. This was illustrated by the national artists like Carlos "Botong" Francisco and painter Joselito E. Barcelona in their highly acclaimed works. They depict in their paintings the whole process that involves the literal carrying of a house to its new location. The act depicts the common tradition in the Philippines where community members would volunteer to help a family move their residence to a new place. The said activity will be followed with a small feast prepared of course by the recipient family to express appreciation and gratitude to those who volunteered to help. That whenever somebody helps another without any compensation, that person and the service done is considered as "bayani".

The rootword "bayani" first appeared in the works of the Jesuit Father's. Juan de Noceda and Pedro de Sanlucar published in Manila on 1860, with a title "Vocabulario de la Lengua Tagala". 
In the said work, the term "bayani" means "obra comun" or group work. The cooperative work practiced by the people eventually became known as "bayanihan". Therefore, bayanihan as a communal exercise of giving free services to others is an act of heroism. As such people were called bayani simply because they were able to help those in need.

The term may be understood in several ways as stated previously, but ultimately it may only mean one thing, communal cooperation. However, this Filipino type of communal cooperation is culturally different to that of the Eastern and Western practices. It may not be endemic and peculiar among Filipinos but such term may have come from one and the same notion. The act might be an ancient practical response to both communal and individual needs that would be difficult to achieve if they would not organize and work together. This notion evolved into different beliefs and practices that fits to one's custom, and by convention got different names. This good custom is widespread in the Philippines. In fact many ethnolinguistic groups have their own term for it. The Waray speaking people of Leyte and Samar call it "tiklos", "pintakasi", or "alayon". The Ivatan of Batanes call it "paysidu-sidungan", the Ilokano call it "ammoyo" or "tagnawa", and other Tagalog people also call it "bataris" or "bataresan". The Palawano in the other hand call it "tabang-tabang", other Visayan speaking people call it "tambayayong" the Maranaw call it "kapamagawida" or "kapamagogopa" and the Subanen call it "dundyug" or "sod" (Veneracion, 1996). People may call such custom differently but it has an analogous meaning, which is voluntary, reciprocal and communal work.

However, technological and economic advancement may have significantly changed the notion of this ancient tradition. In some areas, according to some research, there is a disintegration of this traditional reciprocal labor exchange. According to their findings, such disintegration of tradition becomes evident because people began to adopt the cash economy (Ang, 1979). This become evident when multi-companies began to invest in the area and began to hire local workers. People began to work for a fee, and they no longer work for free. The ancient tradition of cooperative labor was now replaced by wage labor. From then on community members no longer depend on other members to help them in their work instead they hire them in exchange for wage. The purpose of this paper is to rediscover this ancient value if it still being practiced by the barrio folks in the countryside. Did technological advancement and economic development change the notion?

This study is anchored on the theory of collective effervescence supported by the idea of communitas and the idea of mutual aid. Collective effervescence was coined by the German sociologist Emile Durkheim. According to this sociological concept, people would at times come together, simultaneously communicate the same idea and lead them to participate in a collective action. This act is possible and do happen when it excites individuals and such experience become the unifying factor. It connects individuals and brought them into close physical proximity. There is a kind of magnets that binds them and elevates them to an extraordinary degree of ecstasy (Tim, 2001). In this study, the concept was utilized to explain the phenomenon on how people come together, participate in a collective act to promote common interests or achieve shared goals and produce a positive uplifting experience.

The concept of "communitas" by Victor W. Turner indicates heightened feelings of social intimacy and belonging, often in connection with rituals. He likewise call this as liminality which 
he referred to as unstructured state in which community members experienced equality. They allowed themselves to share common experiences that transforms them into accepting and creating a new one (Turner, 2005). This concept explains some reasons why people consolidate and participate in a collaborative act to achieve a common goal that would take the community to the next level.

The term mutual aid used to mean a reciprocal voluntary exchange or services and resources for mutual benefit, (Kropotkin, 2008). This is an old tradition among people and is said to be as ancient as the human culture. When man come up with the idea of putting up communities until the invention of farming tools and farming techniques, human beings were considered foragers. In those days, exchanging labor and resources for the benefit of the group and individuals were a common practice. They would hunt, look for root crops and other food as a group and eventually divide what they found among themselves. Therefore, the idea of mutual aid was developed and advanced by mutualism. In this study, the said idea will explain that people come together not because they were excited to do something but the benefit that they would get if they come along. This is characterized as spontaneous and involves mutual give and take.

Kropotkin's theory on mutual aid emphasized on an open model of voluntary cooperation in mutual-aid groups as against to the historic concept of an autonomous individual and to induce cooperation (Kropotkin, 2008). Man does not exist for himself alone because he has to live with others. The idea of man as a wolf to other man no longer exist, instead he began to live with others. Man begun to cooperate with other man for their own mutual benefit. The "bayanihan spirit" attributed to the Filipinos therefore, maybe found in the collective society. According to Hofstede (2005) the way members behave in an individualist and collectivist society are quite distinct. In an individualist society, people are accustomed to look after their individual needs or that of their families. While in a collective society, the members typically operate through networks and association. Members of a collective or collectivist society work in a communal sense (Barton, 2008). In this study, such idea will be utilized to explain why people do converge and work together.

The Chinese for example use a term whose meaning is quite similar to the Filipino bayanihan. The Chinese term "guanxi" focuses on the development of a collective act to help those in need. Operationally, the said term is different to that of the Filipino idea of communal spirit (Barton, 2008). The Filipino communal spirit or "bayanihan" is collective effort to achieve one goal. The effort to achieve a particular objective has been a practice not only by native Filipinos but by other cultures too. This usually took place when people would gather together to accomplish a task which are often doing major jobs or to hold a competition. This undertaking may be clearing a field or constructing a house or a barn, that would be very difficult to carry out alone. Such community work is considered as both social and utilitarian event, because the people involved allow themselves to socialize and at the same time extend a hand to their community member who needs help.

Bowles and Gintis (2011) further strengthen the above mentioned claim. They posit that people cooperate not only for selfish reasons but also because they are genuinely concerned about the well-being of others. People tend to uphold social norms and value behaving ethically not for their personal well-being but for the common good. This act of cooperation is a distinguishing 
feature of human species that creates an atmosphere of unity despite of its diversity. They can evolve cooperation strategies when they participate in groups that share long term similar norms. In the same manner they are also willing to sanction those that do not follow group agreements. Human beings by nature do cooperate, they truly sacrifice for one another on a very large scale and not just with kin. Soldiers for example risk their lives in war for their country and countrymen. People donate money, goods and even blood for unknown others. On a daily basis, people obey all kinds of prosocial norms such as offering a seat to an elderly in a public transport or helping them cross the street. They don't really have to do all those things but, they feel guilt or shamed whenever they breach such norm. According to Tomasello (2011), this is a sure sign that nature has crafted human beings to be cooperative. This work clearly manifested the idea that cooperation among man is innate in their nature. In this study, the said notion will further explain why people would come together and do a collective act. This is a clear manifestation that man was indeed created to be with others. That is why man has to live harmoniously with others.

Another author claims that human behaviors are influenced by shared attitudes, values and identities that reflect social connection rather than material interests. That is why people tend to cooperate with legal authorities responsible for social order in a community. The same is true with employees cooperating with each other in the workplace or citizens cooperating with the government authorities in political communities. The main factor of such achievements are socially driven rather than instrumentally based (Tyler, 2011 \& Lima, 2012). That is why when man shares the same vision and mission, they are compelled to do a collective act. This said idea were utilized to further explain the phenomenon of "bayanihan". Such idea projects a clear picture that collective action is possible because people do share the same vision. And such vision compels them to act uniformly to achieve their intended goal that would give them their collective identity.

Another study further supports the above mentioned idea. The study posits that people coming from all walks of life may come together bringing with them their shared interest, vision and mission. This action may not be caused by external manipulation or of some economic sanction or benefit rather than a common interest. There is something in common that binds them together. That despite of the fact that they do not know each other, the commonality that they possess drives them to act as one (Crowther \& Cooper, 2002; Wilson, B., Hardman, S., Thomam, C. \& Dunlap, J., 2004 \& Freitos, 2005). The commonality between people brought them together to achieve goals. They may practice different cultures but, there is something in them that unites them. That unifiui their common interest.

Many things have already been said about this ancient Filipino tradition. It has been immortalized in several Filipino work of arts such as songs, poems, paintings and plays. The intent of this study is to investigate how and why people come together to solve particular problem in the community. Furthermore, this also tried to rediscover the ancient Filipino value and what aspect of the said tradition called "bayanihan" holds true in contemporary time. This also sought explanation as to why they are still practicing it? What motivates them to do such an act? The $21^{\text {st }}$ century ideas had caused several things to change. People may no longer do voluntary work since everything now is done in exchange for money. Money brought about change in the concept of mutual labor exchange. According to some study, people no longer 
depend on their neighbors in case they built their house and prepare the field for planting. They now hire workers in exchange for money to do the menial jobs that was once done by the community for free (Ang, 1979).

\section{Materials and Methods}

This research will rediscover this Filipino values by reexamining some long ago tradition that is still practiced by the barrio folks. The study was conducted in one of the barangay in Tanauan, Leyte, Philippines. The said barangay was totally devastated by typhoon Haiyan last November 8,2013 . However, they were able to bounce back and rehabilitate those destroyed. They showed to the world how resilient they were despite of the loss they experienced.

This study has two major concerns: first to investigate how and why the "pintakasi or bayanihan" spirit of the past still evident today. And second, to rediscover which aspect of the "pintakasi or bayanihan" spirit and the ancient Filipino value hold true in contemporary times. Such queries were answered using a qualitative research approach specifically the ethnographic method in gathering data. This study focused on the members shared methods for making sense of and achieving social order. The theory posited by Harold Garfinkel, an American sociologist, said that society function on the basis of shared assumptions. This research method will employ a face-to-face interview to establish the meaning and to understand the phenomenon of "pintakasi or bayanihan" from their point of view (Creswell, 2014). Library researches were also done to further deduce some ideas regarding the said practice.

The participants were composed of ten (10) individuals that include the barangay officials, led by their chairperson and some elders of the community. All of them were residents of Barangay Mohon, Tanauan, Leyte, who are practicing "pintakasi or bayanihan". The researcher met and interacted with the participants several times asking them in a form of a face-to face interview about their personal idea on the said practice. The purpose of the method applied was to validate and revalidate the answers the participants provide. There were instances that the researcher paid a visit to participants' homes, farms and places where they make their living to understand the said phenomena.

The lead researcher is a resident of the said barangay. He grow up, mingled and witnessed the unique interactions of the community members. The experience motivated the same to conduct the study to highlight the said local tradition. This study aims to know what the participants do or use in conducting and accomplishing their daily affairs. This will encourage other people to reexamine and look back to their particular traditions in the face of technological advancement and modernization

\section{Results and Discussions}

Based on the related literature cited previously, the said study investigated the community tradition of a barangay that practice the so-called bayanihan in Tagalog, "pintakasi", "pakigalayon" and "pagburubligay" in Waray-waray or community spirit. The respondents were residents of Barangay Mohon, Tanauan Leyte, Philippines. The said community is one of the 54 barangay of the Municipality of Tanauan, Leyte. The said barangay is composed of 347 
households, many of whom are professionals and most are into farming, fishing, tuba gathering and handicraft making. According to the residents of the place, most of its inhabitants were related to each other by blood. They claimed that "an mga taga Barangay Mohon mag-ugrupod la. Kaurogan ha amon miyembro hadi nga tulo nga tuminong-nong nga pamilya, an Songalia, Moreto ug Espina". (The inhabitants of Brgy. Mohon are kin. Most of us here belong to the family with surnames, Songalia, Moreto and Espina). That is why the land that comprises the whole barangay belong mostly to the above mentioned surnames. This is a clear manifestation that there is a very strong kinship system existing in the place. Such system is the basis of the rules being followed by the community. Though politically they have different affiliations but they are united through traditions and other activities that demonstrate concern to their neighbors.

\subsection{Sense of Responsibility}

"We are usually a divisive people but when tragedy strikes, we set aside our political differences and show unity and compassion" said one of the residents of the place. November 8, 2013 for example was a date almost everyone in the barangay would not forget. This day has become synonymous with destruction and loss of both life and property. This is the date when the strongest typhoon ever recorded in history made a land fall in Eastern Visayas region. It was locally called typhoon Yolanda and internationally known as Haiyan. Typhoon Yolanda was catastrophic as the Islands of Leyte and Samar were badly hit by the storm surge that resulted to the destruction of many lives and properties. Despite the odds, the people of both islands who suffered the wrath of the most destructive typhoon ever, were able to survive its aftermath because of this community spirit. The Filipino bayanihan spirit unite the Waraynon in these areas as they helped one another amid the destruction and danger. Stories of heroism were countless people help save other people's lives despite the danger of being drowned, hit by a flying G.I. sheet or by flying and falling debris. Barangay, Mohon, Tanauan, Leyte was not spared by the said catastrophe. They suffered 136 dead all of which died by drowning with several injured, houses and farms totally destroyed.

Although everyone in the area was a victim of the typhoon, it did not hinder themselves from assisting each other whatever was left in their homes like clothing to those who had none, canned food to those who had nothing to eat, and comforting each other's emotional distress. According to several survivors, it was imperative to help despite the reality that he also needed help since there were no other people during those times who would help since relief assistance came late. According to the interviewed survivors, "kinahanglan kami magburublig kay hi kami-kami la it aanhi ngan kami man la gihapon it ma-aapektohan kon deri kami gumi-os". (we need to help each other because we only have each other and it will be us who will get affected if we will not act). The need to help one another became imperative and necessary for their survival. They have to bury the dead bodies of the victims so as to avoid contamination and disease. The barangay officials spearheaded the said clean-up activity but the residents spontaneously came and help. Cadavers, some of which were not known to them, had to be carried to the designated area for mass burial. The community spirit shines in the character of every resident when disaster and tragedy struck them. 
The spirit dubbed as pintakasi or bayanihan must have been ingrained in the culture of this people that enable this disaster to bring out the best in them. The said community spirit could also be attributed to the community's sturdiness or resiliency that almost comes naturally during trying times. They are not ready to fold up. It was surprising to them that selfishness and greed were left-off and pure heart manifested in them. Bowles and Gintis (2011) said that people cooperate not only for selfish reasons but also because they are genuinely concerned about the well-being of others (kapwa).

Even neighboring folks who used to be unfamiliar with each other became better acquaintances as talking and sharing good old stories became the best modes in relieving stress as communication was cut off for a number of days and electricity was down for more than four months. "Waray kami iba nga kalibangan nganhi pagkatapos han Yolanda kundi an magburublig na la" (We have no other means to spend our time on after (typhoon) Yolanda but to help one another) said one of the elected official of the place and was unanimously vouched by everyone.

This incident is probably the most essential in illustrating, "pintakasi", "bayanihan" "alayon" or "burubligay" among Waray-waray people particularly the Mohonanon that showcased to other Filipinos and the world as a whole. The environment struck by said typhoon was devastated and the economy was down to zero. The feeling of helplessness and total discomfort were felt by the survivors. This setback never allowed in themselves to be overpowered. It may be a fact that some individuals took advantage of this suffering like looting, theft and other mischievous activities, the general mood was to be of service and support his fellow victims. When asked what keep them resilient, the usual response was "kay aada man an amon igkasi taga baryo nga mabulig ha amon ngan nasarig kami sa Diyos" (because our barrio-mates are always there to help and we trust God). This means that they are confident that people in the barangay will empathize with them and subsequently help them move on. And they have that deep faith in God that despite what happened they will never be abandoned. Again the concern for the others (kapwa) and their deep faith in God plays a vital rule in the said communal act. This is the very essence of pintakasi or bayanihan, people derived their strength from the community.

The said barangay also had a unique practice in which members of the community would give whatever they can afford to help a bereaved family who belong to the poorest of the poor. The barangay officials would go on a house to house visit to collect anything the community member can give. They can give money, rice or any goods that will be utilized during the wake that would last for days. With the help extended by the community, the bereaved family can now provide food, coffee and snacks to the visitors who would come during the wake. And during burial or "Lubong", the community members in solidarity with the bereaved family would bring the cadaver to the cemetery. After the burial the community would feast on the prepared snack or dinner some of which again were provided by some members of the community or by the bereaved family to express gratitude to those who came. "Nahiaraan na ini namon ha barangay nga buligan adton amon ka barangay nga waray gud. Amo na man gud ini an gin bubuhat han amon mga ka apoy-apoyan nga gin papadayon nala namon yana"(This has been the tradition in our barangay to help those in need. This have been the practice of our ancestors that we simply continue to these days). The community spirit is indeed an inherent trait among them; it is an 
affirmation of their sense of community and communal reliance. This manifests the closeness and intertwined relationship between each community members that even in death they are present to help and comfort each other.

\subsection{Sense of Ownership}

Another scenario would be the Philippine Department of Education (DepEd) annual national program before the start of a new school year called, "Brigada Eskwela". Before it became known as brigade eskwela, the waraynon commonly called it "pintakasi". When asked why, they said that "kay amon man gud ini eskwelahan sanglit kami mismo an mag buburoblig pag maintain hito ngada". (Because that's our school, that is why we ourselves cooperate to maintain that school). Another resident said "dida man gud kami gin tutduan ngan nahibaro sanglit kaupod kami hit pagpaupay hiton eskwelahan kay para liwat hit amon mga anak"(This is where we learn and was taught with so many things, that's why we are part in maintaining the school, because this is for our children). They have that sense of ownership that is why parents and guardians of every student are called in to help the teachers prepare the classrooms for the upcoming school year. They would troop in to the school were their children are enrolled to give voluntary work. Such practice reminds the parents and guardians of their role in the education of their children and for the common good. Through the school, individuals received trainings that prepares them for their individual role in the barangay. Fr. Magsino (2013) believed that the concept of the common good has to do with the idea that in a problem situation facing our society, we are all in it together; it's either we all stay afloat or we all sink together. We cannot go on our own or think only of ourselves. A person who has a clear concept of the common good will think that if he works for the good of society, he will also end up improving his own lot. This concept of common good is our present day concept of "pintakasi or bayanihan".

The act of doing "brigada eskwela" is voluntary and without remuneration. Nevertheless, parents willingly help the teacher prepare and clean the classroom and the surrounding vicinities in order to prepare the opening of the school year. The parents or guardians give out their time, effort and even donate materials such as paints, cement, lumber and other materials which could be used for minor repairs and building. According to some parents, this is the best way of giving back to the government which has been providing free education to its constituents. This is also an avenue for parents to help the school and the teacher where their children are currently enrolled. Besides, the cleanliness and conduciveness of the classroom will primarily be beneficial for their children. Beyond the material and financial benefits generated from the brigada eskwela, the school is also gaining benefit from the goodwill generated when volunteer stakeholders exert for the common good. As an experiential learning activity it teaches the students the importance of community and of humanity which forms the center of the Filipino Spirit.

\subsection{Sense of Belongingness}

The said activity is now the present-day description of the well-known bayanihan spirit -the longtime tradition of volunteerism the Filipinos value most. This good practice known as pintakasi is evident in the idea of Tyler (2011) that human behaviors are influenced by shared attitudes, values and identities that reflect social connection rather than material interests. That is why people tend to cooperate with legal authorities responsible for social order in a community. 
The same is true with employees cooperating with each other in the workplace and citizens cooperating with the government authorities in political communities. During fiesta celebration for example, the whole community is involved in the preparations. Barangay folks can be easily mobilized if one uses the term "pagburublig kita nga tanan para magin malinangpuson ini nga aton selebrasyon hit patron" (we have to cooperate and help each other so we can have a successful celebration of our fiesta). Some community members were assigned to clean the surrounding, others prepare the chapel while others attend to the daily activities. They are doing this act not only because they need to cooperate but more so as a way of thanking God for the blessings received. They said that "an pag selebrar han amon patron usa namon nga pagpakita han amon pagkaurosa ha pasasalamat ha Diyos han mga grasya nga amon nakarawat."(The fiesta celebration is our way of showing our cooperation in thanking the Almighty God for all His blessings). The fiesta celebration does not only pertain show casing what the place have and how they entertain visitors. It is more of a collective expression of thanks giving to the heavenly patron, the renewal of individual's spiritual life and consciousness of membership in the church (Palispis, 2007). Community spirit is upheld during the said activity because residents manifest their individual desire to help. Therefore, the celebration of the fiesta become successful because of the communal cooperation shown by the residents.

\subsection{Sense of Association}

Further, there is another practice in this place that is still being religiously practiced with respect to "pintakasi". This community activity called "alayon" is associated with farming activity. This is the process where during farming, farmers from the neighboring area would flock together in order to help plant rice seedlings. A farmer residing in the place said that "nag buburublig kami nganhi para maka-tanum kami nga tanan ngan para liwat magkamayada anihon para amon pagkaon" (we help each other here so that we can plant and so that we will have something to harvest later for our food). In the past, these farmers would help without any monetary consideration, but only a benevolent share of the harvest after a few months. Notwithstanding the fact that during the day's work these farmers are given food for free by the landowner. "An importante ha amon an mabuligan namon an tagsa-tagsa para nga tanan umasenso" (What is very important to each and every one of us is to be able to help one another to succeed). According to these farmers, they would not mind if they did it for free and the share would still be given afterwards. The essence of it is more on helping another person since if they would not extend assistance, the landowner would not be able pursue planting and the seedlings would be wasted.

In recent years, this practice has evolved to a certain degree. A minimal amount is now accepted by some of these farmers aside from the food during the day's work and the share of the harvest in the future. According to some farmers, the essence of helping is still at its core but for economic considerations of present times have led the idea of asking for a minimal amount for the benefit of these farmers' respective families. Time may have affected in part the concept of "pintakasi" but the very core idea of the said ancient values lives on. They are still willing to help one another in order to achieve a greater good that is progress. 


\section{Conclusions and Recommendations}

Based on the results of the study, the following were derived;

The residents of the said barangay in Tanauan, Leyte are still practicing the tradition known to them as "pintakasi", "pagburublig" or "alayon" which is also known among the majority of Filipinos as "bayanihan". The said practice may not be endigenous to the place but it is good to note that it is still in place and practiced. One of the many factors that encourage the people to hold on the said tradition is their blood bond or kinship. Majority of the residents of the place were related to each other by blood. Their traditions and practices were shape and put in place by the said bond. While it is true that each family is a member of different political alliances, helping each other goes beyond it. That bond is so strong that even the strongest typhoon ever recorded failed to break it, rather they become stronger and resilient to what had happened.

Another driving factor that also manifest is their sense of ownership of the place. They identify themselves with the place, and that is the reason why they were always willing to participate and cooperate. Pintakasi or community spirit is viewed as a duty and a responsibility rather than a burden. They offer free service to the community for the good of its members. They help in the cleaning, repairs and even in farming for the same reason.

Pintakasi or bayanihan is still existent and prevalent among the Waray in particular and the Filipino people. It is innate among this people to help another person who needs assistance. It may be a fact that in few instances monetary considerations may now be asked by some people in exchange for the aid, but these are just in few occasions.

Pintakasi or bayanihan is a unique Filipino values that is worth more than any material possessions. The message of community is deep within them. They were heroes because of this tradition they possess true and genuine heart that are ready to extend a hand to others. In it, they manifest their dignity and with it they become more resilient and brave enough to face adversities.

In the exercise of pintakasi or bayanihan, the concern for others (kapwa) is always at the forefront. Filipino value of "kapwa" is inseparable from the concept of pintakasi or bayanihan for it is a vital factor in accomplishing its real meaning.

Pintakasi also known among Waray-waray speaking people as "pagburublig or "alayon" and "bayanihan" for Tagalog speaking people, is a factor to progress. It is a cultural trait that creates the spirit that encourages services, mutual helpfulness and friendship. The same are the key to progress and development.

In general, these people can extend support in a variety of ways most especially in the most troubling and trying times. In fact, a simple smile and thank you are enough and the person who helped is somehow contented that he was able to help a person in dire need. 
Time must have changed a lot of aspects in the society, and differences, conflicts, and encounters are undeniable, but the fact remains that a helping heart of this people still burns deep inside that when there is a need to help, they help no matter what.

Above all "bayanihan" is a collective expression of the community to serve the Almighty God by serving its people in the community.

\section{Acknowledgements}

This humble work is wholeheartedly dedicated to the following who served as the researcher's source of inspiration towards making this piece of work a reality:

- To the Almighty God who poured His overflowing blessings and spiritual guidance as we went along the way in conducting this study. Without His presence, all my efforts and sacrifices would have useless.

- To our love ones, whose inspiration, encouragement, financial support, love, and care pushed us to finish this study?

- To our research advisers, Dr. Generoso N. Mazo, Dr. Marietta B. Manaog and Prof. Jose N. Lianza, who gave us their full support, and motivation to make this study a fruitful one. We thank them for their generosity of thoughts in providing suggestions and constructive comments to improve this study;

- To our university President, Dr. Jude A. Duarte for his encouragement and financial support.

- To Pais Dr. Sheldon Ives Agaton and his equally supportive wife, Shiela Agaton, who encouraged, advised and made substantial contribution as we look for answers to this research problem.

Thank you very much.

\section{References}

[1] Ang, G., The bayanihan spirit: dead or alive, Philippine Quarterly of Culture and Society, University of San Carlos publication. Vol. 7 (1/2) 1979.

[2] Borton,S.M.,Cultural factors that influence the uptake of e-learning in Malaysia Academic Guanxi, World conference on e-learning in corp., government, healthcare and higher education. 2008

[3] Bowles \& Gintis, A cooperative species: Human reciprocity and its evolution, Princeton University Press, Princeton, New Jersey,2011.

[4] Creswell, W., Research design: qualitative, quantitative and mixed method approach, $4^{\text {th }}$ ed. SAGE publication inc., Washington D.C., U.S.A., 2014.

[5] Collins Spanish-English Dictionary, $9^{\text {th }}$ Edition, William Collins Sons Co., 2011.

[6] Crouch, C., Eder, K. \& Tambini, D., Citizenship, markets and the state, Oxford University Press, 2004.

[7] Crowther D., \& Cooper S., (2002), Rekindling community spirit and identity: the role of ecoprotestors, Management decision, Vol. 40(4), 2002, 343-353

[8] De Noceda,J. \& De San Lucar P., Vocabulario de la lengua tagala(Microform) de Ramirez y Giraudier, Manila, Philippines, 1860.

[9] Hofstede, G., Culture and organization:software of the mind, McGraw-Hill,New York, 2005.

[10] Ilada, A., Understanding the Filipino, New day publishing, Quezon City, Philippines, 1987. 
[11] Jocano, F.L., Filipino values system: A cultural definition, Punlad Research House, Inc., Quezon City, Philippines, 1977.

[12] Jocano, F.L., Filipino worldview: Ethnography of local knowledge, Punlad Research House, Inc., Quezon City, Philippines, 2001.

[13] Kropotkin, P., Mutual aid: A factor of evolution, Forgotten books, Charlestone SC, 2008.

[14] Faleiros, V.,Challenges of social work in the face of social inequalities, Revista Emancipaco 11(1), 2011.

[15] Fr. De Lisboa, M., Vocabulario de la lengua bicol, Establecimiento Tiporafico del Colegio de Santo Tomas, Manila, 1865

[16] Fr. Magsino, C., Present-day "bayanihan”, Philippine daily inquirer, Manila Philippines, 2013.

[17] Fr. Mercado, L., SVD., Filipino thought on Man and Society, Divine Word University Publication, Tacloban, Philippines, 1980.

[18] Freitos, A., Arte e movimento estudantil analise de uma obra de Antonio Manuel, Revista Brasileira de Historia,2005, 25(49).

[19] Krawczyk, V., Bruce, M., Koblar, S., \& Crichton, J., Group organization and communities of practice in translation research, SAGE open, 2014, 4(4).

[20] Lima, M., Cooperative: A female experience in the art of producing success, Revista Estados Feminista,2012, 20(1).

[21] Merriam-Webster Spanish-English Dictionary, Merriam Webster, Inc., 1998.

[22] Nwanaju Uzoma T., Can culture unite? An explorative gestalt of Iwa akwa and seigbein festivals, Journal of arts and humanities,2013, 2(4)

[23] Panopio, I. \& Raymundo A., Sociology: Focus on the Philippines, Ken Inc., Quezon City Philippines, 2004.

[24] Palispis, E.S., Introduction to sociology and anthropology, Rex books store, Manila Philippines, 2008.

[25] Rosell, M., La historia es de los poetas: tradicion y critica en algunas voces del 27, Olivar: Revista de Literature y Cultura Espanoles, 2009, 10(13)

[26] Sanchez-Cuenca, I., Cooperar por principio, Revista International de Sociologia, 2007, 65(46).

[27] Soter, M., Theoretical modeling of intercultural communication process, Journal of Advocacy, Research and Education, 2016, 6(2).

[28] Tim,O., Collective effervescence and communitas: Processual models of ritual and society in Emile Durkheim and Victor Turner, Kluwer academic publishers, Netherlands 2001.

[29] Tomasello, M., Why we cooperate, the montreal review, Montreal, Canada, 2011.

[30] Tyler, T., Why people cooperate: the role of social motivations, Princeton University Press, Princeton, New Jersey, 2011.

[31] Turner, V., Rituals and Communitas, Creative resistance, 2005, retrieved from http:// citationmachine.net

[32] Veneracion, M.C., Pagtulong, konseptong Pilipino, Kaiser Press, Philippines, 1996

[33] Wilson, B., Hardman, S., Thomam, C., \& Dunlap, J., Bounded Community: Designing and facilitating learning communities in formal courses, 2004, 5(3).

[34] Wojtyla K., The person: Subject and community, Review of metaphysics, 1979, 33(2)

\footnotetext{
*Corresponding author.

E-mail address: dennisbautista1974@ yahoo.com
} 